\title{
Metal interference on luciferase activity induced by 2,3,7,8-tetrachlorodibenzo- $p$-dioxin in bioassays of recombinant mouse hepatoma cells
}

\author{
I-Cheng Chou ${ }^{\mathrm{a}, \mathrm{b}}$, Yee-Lin Wu ${ }^{\mathrm{a}, \mathrm{b}, *}$, Lin-Chi Wang ${ }^{\mathrm{c}}$, Guo-Ping Chang-Chien ${ }^{\mathrm{c}}$, Hsinyu Lee ${ }^{\mathrm{d}}$ \\ a Department of Environmental Engineering, National Cheng Kung University, Tainan 70101, Taiwan \\ b Sustainable Environment Research Center, National Cheng Kung University, Tainan 70101, Taiwan \\ ${ }^{c}$ Department of Chemical and Materials Engineering, Cheng Shiu University, Kaohsiung 833, Taiwan \\ d Department of Life Science, National Taiwan University, Taipei 106, Taiwan
}

\section{A R T I C L E I N F O}

\section{Article history:}

Received 28 June 2008

Received in revised form 20 October 2008

Accepted 20 October 2008

Available online 5 November 2008

Keywords:

PCDDs

PCDFs

Metals

CALUX

Bioassays

\begin{abstract}
A B S T R A C T
This study will examine the effect of a series of metals on the luciferase activity expression induced by 2,3,7,8-tetrachlorodibenzo-p-dioxin (2,3,7,8-TCDD) in H1L6.1 cells. A 2-level factorial design was employed to identify major influential metal species of four test metals $\left(\mathrm{As}^{5+}, \mathrm{Cr}^{6+}, \mathrm{Cd}^{2+}\right.$, and $\left.\mathrm{Pb}^{2+}\right)$ in the chemically activated luciferase expression (CALUX) of H1L6.1 cells.

The observed data revealed that $\mathrm{Cr}^{6+}$ exerted a significant inhibiting effect on the luciferase activity. The impact of key metal species at various concentrations was analyzed for determination of the maximum tolerable level for H1L6.1 cell. It was observed that $\mathrm{Cr}^{6+}$ lowered the luciferase activity by 36.1 and $65.4 \%$, at levels of 1.0 and $1.5 \mu \mathrm{g}-\mathrm{Cr} / \mathrm{mL}$-medium $(p<0.05)$, respectively, but showed no significant difference at higher $\mathrm{Cr}^{6+}$ concentrations (2.0-5.0 $\mu \mathrm{g}-\mathrm{Cr} / \mathrm{mL}$-medium).
\end{abstract}

(C) 2008 Elsevier B.V. All rights reserved.

\section{Introduction}

Polychlorinated dibenzo- $p$-dioxins and polychlorinated dibenzofurans (PCDD/Fs) are carcinogenic and persistent anthropogenic aromatic hydrocarbons. A high-resolution gas chromatograph coupled with a high-resolution mass spectrometer (HRGC/HRMS) is currently the most common analytical method for dioxins in the world, even though bioassay methods have also been developed that are faster (about 5-10 days) and less expensive (about USD. 350-700/sample) than HRGC/HRMS analysis (about 40 days, USD. 1400 /sample). The chemical-activated luciferase gene expression (CALUX) bioassay is currently one of the preferred bioassay because of its high stability and sensitivity [1-3]. CALUX bioassay systems use mouse (Hepa1c1c7) cells that have been stably transfected with the Aryl hydrocarbon receptor (AhR) responsive reporter plasmids pGudLuc1.1 [4].

The CALUX bioassay has been applied to measure the PCDD/F content in various matrices, including marine animal [2,5-7], foodstuff $[8,9]$, human tissue [10-12], and environmental media [3,13]

\footnotetext{
* Corresponding author at: Department of Environmental Engineering, National Cheng Kung University, No. 1 University Road, Tainan City 70101, Taiwan. Tel.: +886 6 2386764; fax: +8866 62752790 .

E-mail address: ylwu@mail.ncku.edu.tw (Y.-L. Wu).
}

CALUX analyzes not only PCDD/Fs and co-PCBs but also those compounds that can bind to and activate the AhR (AhR ligands) [14]. The observed AhR ligands include toxic chemicals (e.g., PBBs, PAHs, PCDE, etc. [14-16]) and naturally occurring compounds (e.g., flavonoids found in vegetables [17], fruits [17], and tea [18]). This suggests that the AhR ligands may interfere with the signal of dioxins and co-PCBs. Chao et al. showed in vitro evidence that arsenic inhibited the TCDD-induced CYP1A1 activation in human hepatoma cells [5], implicating that some metals could interfere with the CALUX bioassay.

To substantiate the speculated metal interference in the CALUX assay, this study analyzed results of 2,3,7,8-TCDD solutions spiked with four environmentally important metals: arsenic $\left(\mathrm{As}^{5+}\right)$, chromium $\left(\mathrm{Cr}^{6+}\right)$, cadmium $\left(\mathrm{Cd}^{2+}\right)$, and lead $\left(\mathrm{Pb}^{2+}\right)$. The reported results used a XDS-CALUX, H1L6.1 mouse hepatoma cell line with a 2-level factorial design. The significant main effects were evaluated by statistical methods, and the relationship between the changes in relative light unit (RLU) and the metal concentration was examined.

\section{Materials and methods}

The cell-culture medium was composted with RPMI medium $1640,8 \%$ fetal bovine serum, and $1 \%$ penicillin-streptomycin. The phosphate buffered saline (PBS) solution, composed of $80 \mathrm{~g}$ of $\mathrm{NaCl}$, 
Table 1

Reagent list for the experiments.

\begin{tabular}{|c|c|c|}
\hline Reagent & Description & Producer \\
\hline As standard solution & $1000 \mathrm{mg} / \mathrm{L}$ in $5 \% \mathrm{HNO}_{3}$ solution & J.T. Baker (USA) \\
\hline Cd standard solution & $1000 \mathrm{mg} / \mathrm{L}$ in $5 \% \mathrm{HNO}_{3}$ solution & J.T. Baker (USA) \\
\hline Pb standard solution & $1000 \mathrm{mg} / \mathrm{L}$ in $5 \% \mathrm{HNO}_{3}$ solution & J.T. Baker (USA) \\
\hline $\mathrm{Cr}^{6+}$ standard solution & $1000 \mathrm{mg} / \mathrm{L}$ in water & High-Purity Standards (USA) \\
\hline $2,3,7,8-\mathrm{TCDD}$ standards & Nonane solution & Wellington laboratories (Canada) \\
\hline Dimethyl sulfoxide (DMSO) & Purity $>99.5 \%$, plant cell culture tested & Sigma-Aldrich (USA) \\
\hline Luciferase assay system & Gene expression and reporter gene kits & Promega Corp. (USA) \\
\hline Cell culture lysis reagent $(5 \times)$ & Lysis cells before assay & Promega Corp. (USA) \\
\hline Trypan blue & Purity: $0.5 \%$ & BioWest (France) \\
\hline \multirow[t]{2}{*}{ Trypsin-EDTA $(10 \times)$} & & GIBCO (USA) \\
\hline & RPMI medium 1640 & GIBCO (USA) \\
\hline \multirow{3}{*}{ Cell-culture medium } & Fetal bovine serum & GIBCO (USA) \\
\hline & Penicillin-streptomycin & GIBCO (USA) \\
\hline & $\mathrm{NaCl}, \mathrm{GR}$ grade & SHOWA (Japan) \\
\hline \multirow{3}{*}{$\begin{array}{l}\text { Phosphate buffered saline (PBS) } \\
\text { solution }\end{array}$} & $\mathrm{KCl}$, ACS grade & Amresco (USA) \\
\hline & $\mathrm{Na}_{2} \mathrm{HPO}_{4}$, ACS grade & Amresco (USA) \\
\hline & $\mathrm{KH}_{2} \mathrm{PO}_{4}, \mathrm{ACS}$ grade & Amresco (USA) \\
\hline H1L6.1 cell line & A recombinant cell from the mouse hepatoma cell & Xenobiotic Detection Systems Inc. (USA) \\
\hline 96-Well assay plates & Costar 3610 with tissue culture treated & Corning Inc. (USA) \\
\hline Tissue culture flask & $150 \mathrm{~cm}^{2}$ Flask with vented cap & Orange Scientific (Belgium) \\
\hline
\end{tabular}

$2 \mathrm{~g}$ of $\mathrm{KCl}, 11.5 \mathrm{~g}$ of $\mathrm{Na}_{2} \mathrm{HPO}_{4}$, and $2 \mathrm{~g}$ of $\mathrm{KH}_{2} \mathrm{PO}_{4}$ in $10 \mathrm{~L}$ of Milli$\mathrm{Q}$ water, was used to wash the cells. Other reagents are listed in Table 1.

The H1L6.1 cells were placed in tissue culture flasks containing the cell-culture medium and then seeded in 96 well-assay plates in order to carry out the factorial design experiments. The cells were incubated in a HEPA filtered Water Jacketed $\mathrm{CO}_{2}$ incubator (Thermo Forma, USA) at $37^{\circ} \mathrm{C}$.

The analysis matrix was performed in a tray, as shown in Table 2. In each test, vortexed $2 \mu \mathrm{L}$ of $7.8 \mathrm{ng} / \mathrm{L} 2,3,7,8$-TCDD solution in DMSO and $200 \mu \mathrm{L}$ RPMI1640 medium was added to the test plate. The solution was then spiked with a randomly chosen order of metals and incubated for $24 \mathrm{~h}$. After incubation, the luciferase activity and the relative survival rate of the cells were measured as follows.

The luciferase activity was shown in relative light units (RLUs), which were measured in each well using a Wallac VICTOR ${ }^{3} 1420$ Multilabel Counter coupled with a dispenser (PerkinElmer, USA) to automatically inject the luciferase reagent. The obtained RLUs were then analyzed with the Design Expert software (Stat-Ease, USA).

The survival rate was estimated by harvesting the H1L6.1 cells with trypsin-EDTA and then dyeing with $0.5 \%$ trypan blue to count the number of living cells. The H1L6.1 cell survival rate was then determined for each analysis matrix tested.

\section{Results and discussions}

To obtain a clear conclusion of factorial design, the selected low and high concentrations should be have large difference in RLUs and similar relative survival rate. According to the data of rf. [5], the 0 and $1.25 \mu \mathrm{g} / \mathrm{mL}$ medium was selected as low and high level concentration in this study, respectively. Moreover, a factorial design was used to identify the metals which are critical factors to the H1L6.1 cell luciferase activity. A 2-level 4-factorial design $\left(2^{4}\right)$ was used to analyze the luciferase activity in experiments using both low and high metal levels. A total of 32 runs were performed in a batch. The treatments included arsenic $\left(\mathrm{As}^{5+}\right)$, cadmium $\left(\mathrm{Cd}^{2+}\right)$, chromium $\left(\mathrm{Cr}^{6+}\right)$, and lead $\left(\mathrm{Pb}^{2+}\right)$, as shown in Table 2 .

The 2,3,7,8-TCDD calibration curve for the CALUX bioassay was established from the relationship between the concentrations of the 2,3,7,8-TCDD standard solutions $(250,125,62.5,31.3,15.6$, $7.81,3.91,1.95,0.977,0.488$, and $0.244 \mathrm{pg}-\mathrm{TCDD} / \mathrm{mL}$ medium), as shown in our previous study [19]. For the tests to be significant,

Table 2

Influence of spiked $\mathrm{As}^{5+}, \mathrm{Cr}^{6+}, \mathrm{Cd}^{2+}$, and $\mathrm{Pb}^{2+}$ on the luciferase activity in matrix tests.

\begin{tabular}{|c|c|c|c|c|c|c|c|}
\hline \multirow{2}{*}{$\begin{array}{l}\text { Yate's standard } \\
\text { order }\end{array}$} & \multirow[t]{2}{*}{ Spiked metals } & \multirow{2}{*}{$\begin{array}{l}\text { Treatment } \mathrm{As}^{5+} \\
(\mu \mathrm{g} / \mathrm{mL})\end{array}$} & \multirow{2}{*}{$\begin{array}{l}\text { Treatment } \mathrm{Cr}^{6+} \\
(\mu \mathrm{g} / \mathrm{mL})\end{array}$} & \multirow{2}{*}{$\begin{array}{l}\text { Treatment } \mathrm{Cd}^{2+} \\
(\mu \mathrm{g} / \mathrm{mL})\end{array}$} & \multirow{2}{*}{$\begin{array}{l}\text { Treatment } \mathrm{Pb}^{2+} \\
(\mu \mathrm{g} / \mathrm{mL})\end{array}$} & \multicolumn{2}{|c|}{ Luciferase activity (RLUs) } \\
\hline & & & & & & Assay 1 & Assay 2 \\
\hline 1 & - & 0 & 0 & 0 & 0 & 34,646 & 31,156 \\
\hline 2 & As & 1.25 & 0 & 0 & 0 & 53,683 & 57,207 \\
\hline 3 & $\mathrm{Cr}$ & 0 & 1.25 & 0 & 0 & 2,047 & 2,054 \\
\hline 4 & As, $\mathrm{Cr}$ & 1.25 & 1.25 & 0 & 0 & 4,771 & 4,766 \\
\hline 5 & $\mathrm{Cd}$ & 0 & 0 & 1.25 & 0 & 33,610 & 44,813 \\
\hline 6 & As, Cd & 1.25 & 0 & 1.25 & 0 & 32,799 & 39,824 \\
\hline 7 & $\mathrm{Cr}, \mathrm{Cd}$ & 0 & 1.25 & 1.25 & 0 & 2,160 & 2,126 \\
\hline 8 & As, $\mathrm{Cr}, \mathrm{Cd}$ & 1.25 & 1.25 & 1.25 & 0 & 3,742 & 3,780 \\
\hline 9 & $\mathrm{~Pb}$ & 0 & 0 & 0 & 1.25 & 41,027 & 55,772 \\
\hline 10 & As, $\mathrm{Pb}$ & 1.25 & 0 & 0 & 1.25 & 35,424 & 41,616 \\
\hline 11 & $\mathrm{Cr}, \mathrm{Pb}$ & 0 & 1.25 & 0 & 1.25 & 3,223 & 3,455 \\
\hline 12 & $\mathrm{As}, \mathrm{Cr}, \mathrm{Pb}$ & 1.25 & 1.25 & 0 & 1.25 & 1,559 & 1,486 \\
\hline 13 & $\mathrm{Cd}, \mathrm{Pb}$ & 0 & 0 & 1.25 & 1.25 & 62,971 & 55,469 \\
\hline 14 & As, $\mathrm{Cd}, \mathrm{Pb}$ & 1.25 & 0 & 1.25 & 1.25 & 49,375 & 45,653 \\
\hline 15 & $\mathrm{Cr}, \mathrm{Cd}, \mathrm{Pb}$ & 0 & 1.25 & 1.25 & 1.25 & 1,169 & 1,344 \\
\hline 16 & $\mathrm{As}, \mathrm{Cr}, \mathrm{Cd}, \mathrm{Pb}$ & 1.25 & 1.25 & 1.25 & 1.25 & 3,695 & 3,293 \\
\hline
\end{tabular}




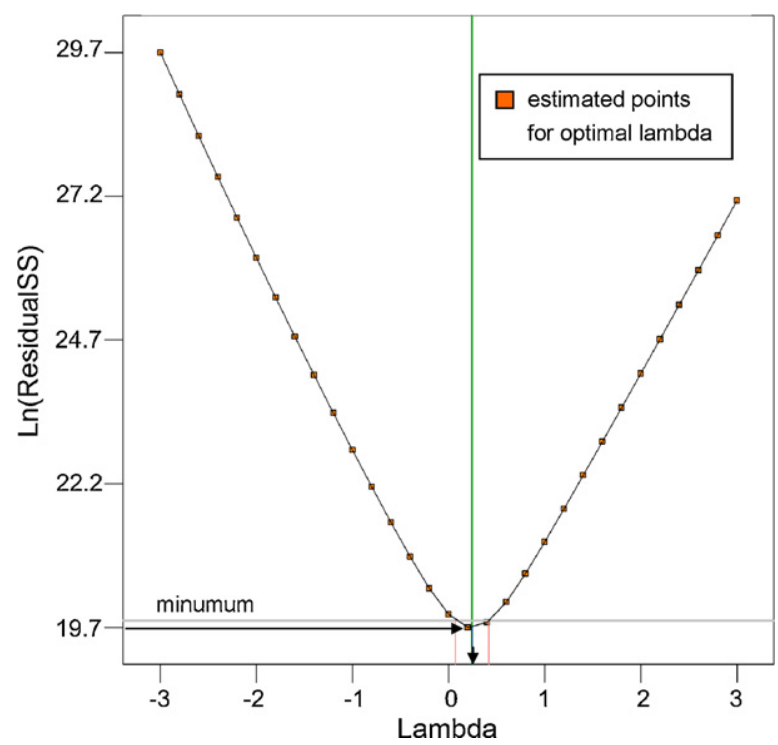

Fig. 1. Box-Cox plot for determining the optimal lambda parameter (0.24) at relative minimum natural logarithm of the sum of the square of residuals.

two criteria must be met. The coefficient of determination $\left(R^{2}\right)$ must be $>0.98$ for the respective luciferase activities (RLUs) of the calibration curve when fitting the data to the 4-parameter Hill's sigmoid curve with least squares algorithm, and the errors for the $2,3,7,8$-TCDD standards must be $<20 \%$. Different from toxicity equivalency factor (TEF) which are defined by multifold experiments, the CALUX relative potency (REP) values are given for congeners to determine the CALUX toxic equivalent (CALUX TEQ). The REP values, refer to potencies relative to TCDD obtained in a single in vitro study, represent the actual potency of the specific congener to activate the AhR pathway $[18,20]$. When the luciferase activity of the 2,3,7,8-TCDD standard corresponds to half of the maximal effective luciferase activity $\left(\mathrm{EC}_{50}\right)$, it is considered representative of the specific toxicity potency of a toxic compound [21]. Thus the 2,3,7,8-TCDD standard with $7.8 \mathrm{pg} / \mathrm{mL}$ was selected for the experiment.

Statistical analysis of experimental data are often assumed that observations are independently [22], however, the residual of each run shown a non-normal distribution for the raw data. Box and Cox (1964) provided an algorithm to transform from raw data $(y)$ to transformed data $\left(y^{\prime}\right)$ with a normal distribution by a parameter $\lambda$ :

$y^{\prime}= \begin{cases}y^{\lambda} & (\lambda \neq 0) \\ \log y & (\lambda=0)\end{cases}$

The algorithm, Box-Cox transformation, was employed to reduce the heterogeneity of error [23], and the optimal $\lambda$ value was determined by a trial-and-error method from -3 to 3 , as shown in Fig. 1 . For each $\lambda$ value, the relative natural logarithm of the sum of the square of residuals, $\ln$ (ResidualSS), was plotted. The $\lambda$ value with minimal $\ln$ (ResidualSS) was the best-fit normal distribution at 0.24 . The luciferase activities from each analytical matrix were transformed with a $\lambda$ order function so that the residuals of transformed data would have an independent identical Gauss distribution (IIDN) shape.

The normal plot is in the form of a semi-logarithmic scale of the normal probability (\%) against the standardized effect. Such a plot reveals the influence of metals and their interactions on the luciferase activity of the CALUX system. The estimated effects on a normal plot of H1L1.6 cell-line tests are shown in Fig. 2(A). The gray and white squares are the positive and negative effects,
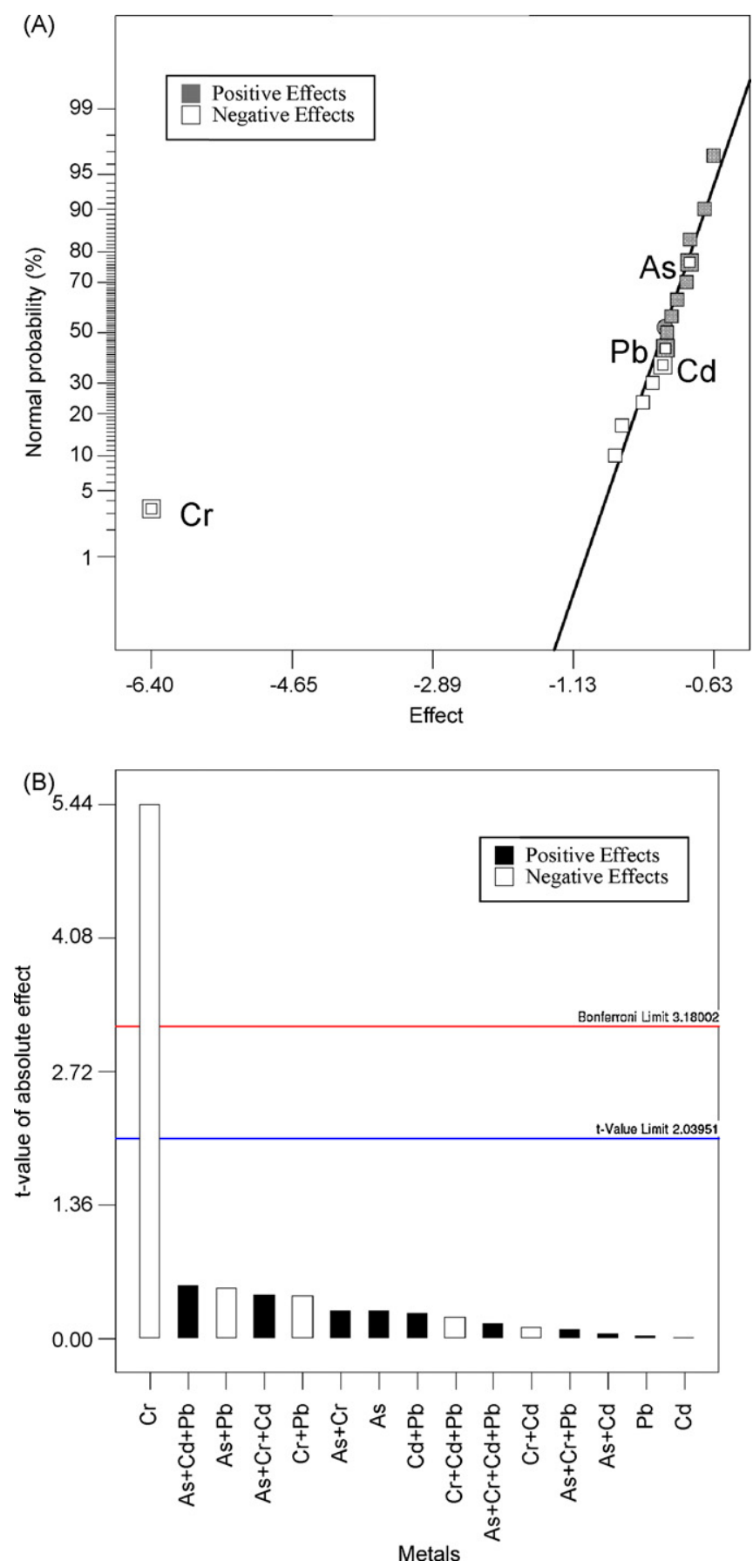

Fig. 2. Normal plot of the H1L1.6 cell line (A) and Pareto plot of effects (B) for the factorial design experiment $(\lambda=0.24)$ to determine the significant effect of selected metals.

respectively. The transformed values should be on the line with a normal distribution situation if there is no significant effect on the response. Fig. 2(A) shows that the effects of four metals and their interactions do approximate a normal distribution, with the exception of the $\mathrm{Cr}^{6+}$ effect. That means the outlier in the plot, treatment $\mathrm{Cr}^{6+}$, did have a significant effect on the system.

To compare the $t$-value of all effects, the rank of the effect of each significant treatment and interaction was plotted in a Pareto chart, as shown in Fig. 2(B). The vertical axis shows the $t$-value of the absolute effects to allow easy comparison with each treatment 


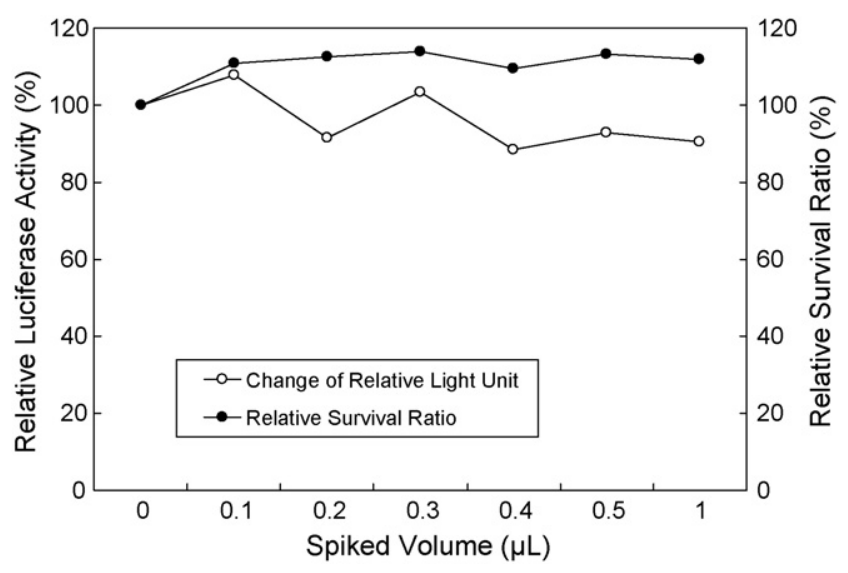

Fig. 3. Relative luciferase activity and relative survival ratio versus the spiked volume with $5 \% \mathrm{HNO}_{3}$ for the $\mathrm{H} 1 \mathrm{~L} 1.6$ cell line.

and interaction effects. The gray and white squares in Fig. 2(A) are the positive and negative effects, respectively. The effect of a treatment and interaction larger than the $t$-value limit was defined as an outlier (i.e., significant effect), as was the case for $\mathrm{Cr}^{6+}$. Fig. 2(A) and (B) demonstrate that chromium(VI) has significant negative effect in the tests.

As stated in Fig. 3, the standard solutions of $\mathrm{As}^{5+}, \mathrm{Cd}^{2+}$, and $\mathrm{Pb}^{2+}$ were made in $5 \% \mathrm{HNO}_{3}$. Assays with $0-1.0 \mu \mathrm{L}$ nitric acid were performed to ascertain whether the nitric acid had a significant effect on the luciferase activity of H1L6.1 cells. The spiked volume $(\mu \mathrm{L})$ of $5 \%$ nitric acid did not show a significantly different effect on the relative luciferase activity (\%) with a pair $t$-test $(p>0.1)$; thus, it had no effect on the relative survival ratios $(\%)(p>0.1)$. This illustrates that $\mathrm{pH}$ range (6.91-7.15) has no significant effect on the luciferase activity of H1L6.1 cells.

Fig. 4(A) and (B), respectively, shows the relative luciferase activity (\%) and relative survival ratio (\%) of the spiked $\mathrm{Cr}^{6+}$ that exhibited significant effects on the luciferase activity. The asterisks show a significant difference with a pair $t$-test $(p<0.05)$ when compared to the experiments not spiked with a metal. The results based on a factorial design help identify the critical metals affecting the luciferase activity of H1L6.1 cells. The influence of chromium(VI) at various concentrations was analyzed three times to determine the maximum tolerable concentration of the H1L6.1 cell line.

As shown in Fig. 4, the chromium(VI) significantly reduced the luciferase activity by 36.1 and $65.4 \%$ when the chromium(VI) concentrations were at 1.0 and $1.5 \mu \mathrm{g}-\mathrm{Cr} / \mathrm{mL}$-medium, respectively, without significant mortality increasing. When chromium(VI) concentration $>2.0 \mu \mathrm{g}-\mathrm{Cr} / \mathrm{mL}$-medium, despite the CALUX signal also has a statistically suppression increasing, the mortality of cells also showed a significant increasing in Fig. 4(B). Thus, the reasons of RLU suppression increasing at high chromium(VI) may cause by the effects of chromium(VI) and the mortality of cells.

Furthermore, the correlation between luciferase activity and metal concentration is different from that of the relative survival ratio of H1L6.1 cells. This reveals that the inhibition effect of chromium(VI) on luciferase activity may be caused not only by the reduction of H1L6.1 cells but also by other mechanisms, such as the reduction of luciferase enzyme production or the inhibition effect of a metal on CYP1A activation. A comparison between Figs. 3 and 4 reveals that the effects of chromium(VI) should be independent of the $\mathrm{pH}$ values.

In addition, as shown in Fig. 4(A), the luciferase activity does not show a statistically significant difference between the highconcentration metal treatment and that spiked with 2,3,7,8-TCDD alone. However, a significant correlation does exist between the
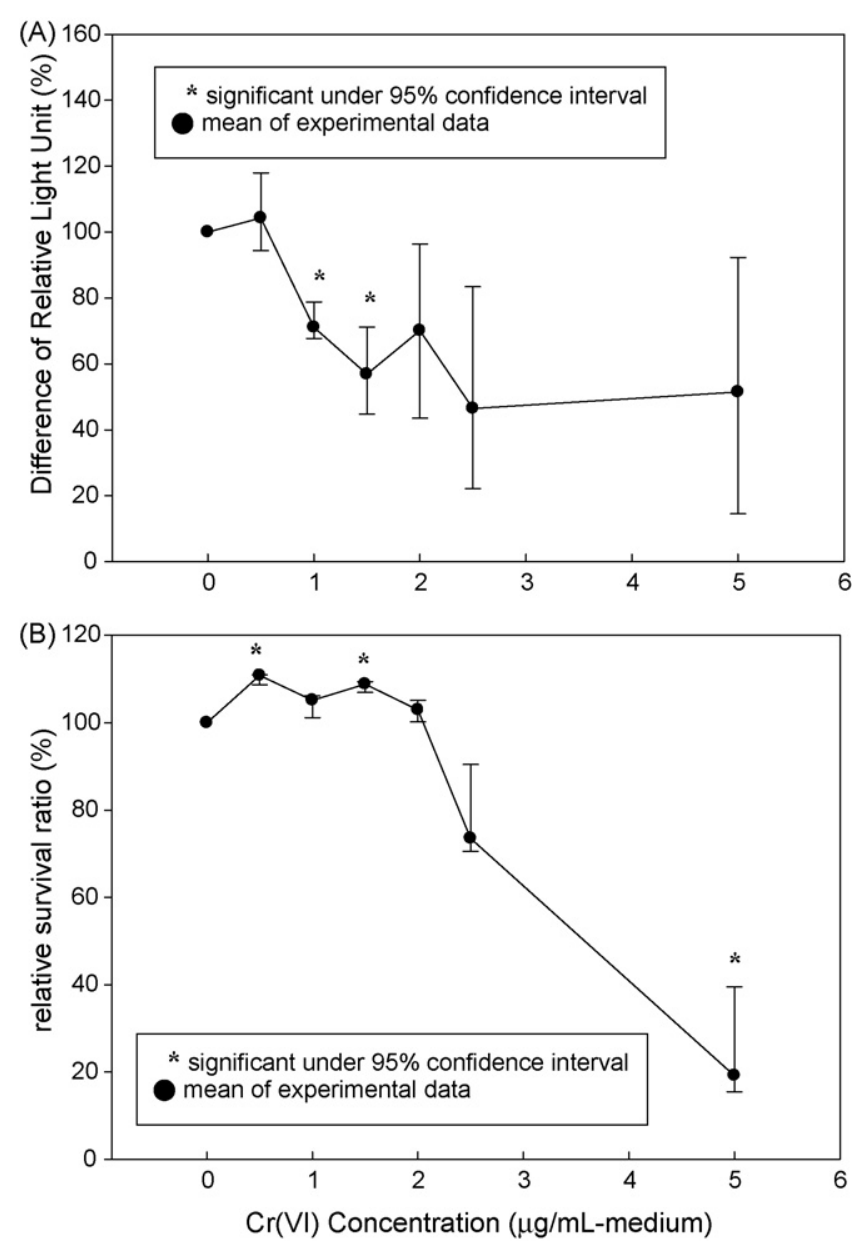

Fig. 4. Relative luciferase activity (A) and relative survival ratio (B) versus the $\mathrm{Cr}^{6+}$ concentration $(n=3)$ with standard deviation interval.

chromium concentration and the standard deviation of RLUs (Pearson correlation $=0.918, p<0.01)$. Furthermore, the cell relative survival ratios also show results similar to those with chromium (Pearson correlation $=0.90, p<0.01$ ). This implies that the metal treatment is a possible interference factor to the H1L6.1 cell line, even though the luciferase activity does not show a statistically significant difference with added chromium.

The high levels selected metals is equal to $0.1 \mathrm{mg} / \mathrm{kg}$ of $10 \mathrm{~g}$ soil sample, without consider any loss, which is as low as background soil level in Taiwan. That reveals the chromium(IV) still could be a potential interference factor to the CALUX bioassay system without a probably pretreatment process, though the environmental samples are not contaminated by heavy metals.

\section{Conclusions}

In this paper, a factorial design was used to identify the critical metal effect among arsenic $\left(\mathrm{As}^{5+}\right)$, chromium $\left(\mathrm{Cr}^{6+}\right)$, cadmium $\left(\mathrm{Cd}^{2+}\right)$, and lead $\left(\mathrm{Pb}^{2+}\right)$ on the luciferase activity of the H1L1.6 cell. The outcome of factorial design reveals that only $\mathrm{Cr}^{6+}$ had a significant effect on H1L6.1 cells among arsenic $\left(\mathrm{As}^{5+}\right)$, chromium $\left(\mathrm{Cr}^{6+}\right)$, cadmium $\left(\mathrm{Cd}^{2+}\right)$, and lead $\left(\mathrm{Pb}^{2+}\right)$. Moreover, the influence of $\mathrm{Cr}^{6+}$ (on RLUs) increased with increasing metal concentration. However, an increase in the concentration of nitric acid does not show a significant effect on the luciferase activity of the H1L6.1 cell. This reveals that the effect of $\mathrm{Cr}^{6+}$ appears to be independent of the $\mathrm{pH}$ range of culture medium. 
Furthermore, the correlation between luciferase activity and metal concentration is different from that of the relative survival ratio of H1L6.1 cells when the chromium(VI) concentration $<2.0 \mu \mathrm{g}$ $\mathrm{Cr} / \mathrm{mL}$-medium. This reveals that the inhibition effect of $\mathrm{Cr}^{6+}$ on the luciferase activity may be caused not only by the reduction of H1L6.1 cells but also by other mechanisms. The effects of arsenic $\left(\mathrm{As}^{5+}\right)$, cadmium $\left(\mathrm{Cd}^{2+}\right)$, and lead $\left(\mathrm{Pb}^{2+}\right)$ on H1L6.1 cells were not significant. This study reveals that the effect of metals should be taken into account for the CALUX bioassay when the analytical samples (e.g., sediments or soil) contain a high concentration of metals.

\section{Acknowledgements}

The authors thank Dr. Liang-Ming Whang for advising on experimental designs and Mr. Fu-Guan Chen for helping in the experimental performance and technical support.

\section{References}

[1] A. Dindal, E. Thompson, L. Aume, S. Billets, Application of site-specific calibration data using the CALUX by XDS bioassay for dioxin-like chemicals in soil and sediment samples, Environ. Sci. Technol. 41 (2007) 8376-8382.

[2] I. Windal, N.V. Wouwe, G. Eppe, C. Xhrouet, V. Debacker, W. Baeyens, E.D. Pauw, L. Goeyens, Validation and interpretation of CALUX as a tool for the estimation of dioxin-like activity in marine biological matrixes, Environ. Sci. Technol. 39 (2005) 1741-1748

[3] USEPA, Technologies for Monitoring and Measurement of Dioxin and Dioxinlike Compounds in Soil and Sediment, in: USEPA office and research and development, ed., Innovative Technology Verification Report, USEPA office and research and development, 2005.

[4] M.S. Denison, B. Zhao, D.S. Baston, G.C. Clark, H. Murata, D. Han, Recombinant cell bioassay systems for the detection and relative quantitation of halogenated dioxins and related chemicals, Talanta 63 (2004) 1123-1133.

[5] H.-R. Chao, T.-C. Tsou, L.-A. Li, F.-Y. Tsai, Y.-F. Wang, C.-H. Tsai, E.E. Chang, Z.-F. Miao, C.-H. Wu, W.-J. Lee, Arsenic inhibits induction of cytochrome P450 $1 \mathrm{~A} 1$ by 2,3,7,8-tetrachlorodibenzo- $p$-dioxin in human hepatoma cells, J. Hazard. Mater. 137 (2006) 716-722.

[6] R. Hoogenboom, T. Bovee, W. Traag, R. Hoogerbrugge, B. Baumann, L. Portier G.V.D. Weg, J.D. Vries, The use of the DR CALUX® bioassay and indicator polychlorinated biphenyls for screening of elevated levels of dioxins and dioxin-like polychlorinated biphenyls in eel, Mol. Nutr. Food Res. 50 (2006) 945-957.

[7] T. Tsutsumi, Y. Amakura, M. Nakamura, D.J. Brown, G.C. Clark, K. Sasaki, M. Toyoda, T. Maitani, Validation of the CALUX bioassay for the screening of PCDD/Fs and dioxin-like PCBs in retail fish, Analyst 128 (2003) 486-492.
[8] R. Hoogenboom, The combined use of CALUX bioassay and the GC-HRMS method for the detection of novel dioxin sources and new dioxin-like compounds, Environ. Sci. Pollut. Res. 9 (2002) 304-306.

[9] M.-L. Scippo, G. Eppe, E.D. Pauw, G. Maghuin-Rogister, DR-CALUX(R) screening of food samples: evaluation of the quantitative approach to measure dioxin, furans and dioxin-like PCBs, Talanta 63 (2004) 1193-1202.

[10] P. Laier, T. Cederberg, J.C. Larsen, A.M. Vinggaard, Applicability of the CALUX bioassay for screening of dioxin levels in human milk samples, Food Addit. Contam. 20 (2003) 583-595.

[11] M. Warner, B. Eskenazi, D.G. Patterson, G. Clark, W.E. Turner, L. Bonsignore, P. Mocarelli, P.M. Gerthoux, Dioxin-like TEQ of women from the Seveso, Italy area by ID-HRGC/HRMS and CALUX, J. Expo. Anal. Environ. Epidemiol. 15 (2005) 310-318.

[12] N.V. Wouwe, I. Windal, H. Vanderperren, G. Eppe, C. Xhrouet, A.-C. Massart, N. Debacker, A. Sasse, W. Baeyens, E.D. Pauw, F. Sartor, H.V. Oyen, L. Goeyens, Validation of the CALUX bioassay for PCDD/F analyses in human blood plasma and comparison with GC-HRMS, Talanta 63 (2004) 1157-1167.

[13] H. Sanctorum, I. Windal, V. Hanot, L. Goeyens, W. Baeyens, Dioxin and dioxinlike activity in sediments of the Belgian coastal area (Southern North Sea), Arch. Environ. Contam. Toxicol. 52 (2007) 317-325.

[14] C. Schroijen, I. Windal, L. Goeyens, W. Baeyens, Study of the interference problems of dioxin-like chemicals with the bio-analytical method CALUX, Talanta 63 (2004) 1261-1268.

[15] P.A. Behnisch, K. Hosoe, S.-I. Sakai, Combinatorial bio/chemical analysis of dioxin and dioxin-like compounds in waste recycling, feed/food, humans/wildlife and the environment, Environ. Int. 27 (2001) 495-519.

[16] G. Suzuki, H. Takigami, Y. Kushi, S.-I. Sakai, Evaluation of mixture effects in a crude extract of compost using the CALUX bioassay and HPLC fractionation, Environ. Int. 30 (2004) 1055-1066.

[17] M.G.L. Hertog, P.C.H. Hollman, M.B. Katan, Content of potentially anticarcinogenic flavonoids of 28 vegetables and 9 fruits commonly consumed in the Netherlands, J. Agric. Food Chem. 40 (1992) 2379-2383.

[18] H. Besselink, A. Jones, M. Pijnappels, A. Swinkels, K. Fjellanger, A. Brouwer, Comparison of DR-CALUX ${ }^{\circledR}$ and HRGCMS-derived TEQ's: introduction of conversion factors, Organohalogen Compd. 60 (2003) 203-206.

[19] I-C. Chou, W.-J. Lee, L.-C. Wang, G.-P. Chang-Chien, W.-S. Lee, H. Lee, Validation of the CALUX bioassay as a screening and semi-quantitative method for PCDD/F levels in cow's milk, J. Hazard. Mater. 154 (2008) 1166-1172.

[20] S. Carbonnelle, J.V. Loco, I.V. Overmeire, I. Windal, N.V. Wouwe, S.V. Leeuwen, L. Goeyens, Importance of REP values when comparing the CALUX bioassay results with chemoanalyses results: example with spiked vegetable oils, Talanta 63 (2004) 1255-1259.

[21] D.J. Brown, M. Chu, I. Van Overmeire, A. Chu, G.C. Clark, Determination of REP values for the CALUX ${ }^{\circledR}$ bioassay and comparison to the WHO TEF values, Organohalogen Compd. 53 (2001) 211-214.

[22] G.E.P. Box, D.R. Cox, An analysis of transformations, J. R. Stat. Soc. Ser. B (Methodological) 26 (1964) 211-252.

[23] M.R. Peltier, C.J. Wilcox, D.C. Sharp, Technical note: application of the Box-Cox data transformation to animal science experiments, J. Anim. Sci. 76 (1998) 847-849. 